\title{
WT1 mRNA-Electroporated Autologous Dendritic Cell Vaccine
}

National Cancer Institute

\section{Source}

National Cancer Institute. WT1 mRNA-Electroporated Autologous Dendritic Cell Vaccine.

NCI Thesaurus. Code C88260.

A cancer vaccine containing autologous dendritic cells electroporated with full-length mRNA encoding Wilms' tumor 1 (WT1) antigen with potential immunostimulatory and antineoplastic activities. Upon administration, WT1 mRNA-electroporated autologous dendritic cell vaccine may elicit a cytotoxic $T$-cell $(C T L)$ response against tumor cells expressing WT 1. Wt1 is frequently overexpressed in a variety of tumor cell types and often correlates with disease progression and poor prognosis. 